\title{
SURVEY ON CORRECTIONAL CENTRE YOUTH \\ - STAFF OPINIONS ON SURVEY RESULTS \\ AND ON RECOMMENDATIONS FOR PRACTICE
}

BADANIA MŁODZIEŻY Z OŚRODKÓW

SOCJOTERAPEUTYCZNYCH I WYCHOWAWCZYCH

- WYNIKI I REKOMENDACJE DLA PRAKTYKI

W OPINII PERSONELU TYCH OŚRODKÓW

\author{
Agnieszka Pisarska ID, Krzysztof Jan Bobrowski ID, Jakub Greń ID, Krzysztof Ostaszewski ID \\ Public Health Department, Youth Prevention Unit “Pro-M”, Institute of Psychiatry and Neurology, Warsaw, Poland
}

Zakład Zdrowia Publicznego, Pracownia Profilaktyki Młodzieżowej „Pro-M”, Instytut Psychiatrii i Neurologii, Warszawa, Polska

Alcohol Drug Addict 2019; 32 (4): 337-354

DOI: https://doi.org/10.5114/ain.2019.94026

\begin{abstract}
Introduction: The article presents a summary of the most important results of the research project on the prevalence and determinants of the psychoactive substance use and other problem/risky behaviours among youth attending youth sociotherapy centres (MOS) and youth correctional centres (MOW).

Material and methods: Participants were randomly selected students of MOS and MOW from all over the country $(n=1730)$. Data was collected by self-administered questionnaire during school lessons. In addition, 20 individual interviews were conducted with representatives of MOS and MOW staff.
\end{abstract}

\begin{abstract}
Streszczenie
Wprowadzenie: Artykuł prezentuje podsumowanie najważniejszych wyników uzyskanych $\mathrm{w}$ ramach projektu badawczego dotyczącego rozpowszechnienia oraz uwarunkowań używania substancji psychoaktywnych i innych zachowań problemowych/ ryzykownych wśród wychowanków młodzieżowych ośrodków socjoterapii (MOS) i młodzieżowych ośrodków wychowawczych (MOW).

Materiał i metody: Badaną grupę stanowili podopieczni dobranych losowo MOS i MOW z całego kraju $(n=1730)$. Dane zbierano za pomocą audytoryjnych badań ankietowych. Ponadto przeprowadzono 20 wywiadów indywidualnych z przedstawicielami personelu MOS i MOW.
\end{abstract}

Correspondence to/Adres do korespondencji: Agnieszka Pisarska, Zakład Zdrowia Publicznego, Pracownia Profilaktyki Młodzieżowej „Pro-M”, Instytut Psychiatrii i Neurologii, ul. Sobieskiego 9, 02-957 Warszawa, Polska, phone: +48 224582 630, e-mail: agapisar@ipin.edu.pl

Authors' contribution/Wkład pracy autorów: Study design/Koncepcja badania: K. Ostaszewski, A. Pisarska, K.J. Bobrowski, J. Greń; Data collection/Zebranie danych: A. Pisarska, J. Greń; Data interpretation/Interpretacja danych: A. Pisarska, K.J. Bobrowski, J. Greń, K. Ostaszewski; Acceptance of final manuscript version/Akceptacja ostatecznej wersji pracy: A. Pisarska, K.J. Bobrowski, J. Greń, K. Ostaszewski; Literature search/Przygotowanie literatury: A. Pisarska, K.J. Bobrowski K. Ostaszewski, J. Greń; Funds collection/ Pozyskanie środków (finansowania): A. Pisarska, K. Ostaszewski.

No ghostwriting and guest authorship declared./Nie występują zjawiska ghostwriting i guest authorship.

Submitted/Otrzymano: 05.12.2019 • Accepted/Przyjęto do druku: 27.12.2019

(c) 2019 Institute of Psychiatry and Neurology. Production and hosting by Termedia sp. z o.o.

This is an open access article under the CC BY-NC-ND license (http://creativecommons.org/licenses/by-nc-nd/4.0/) 
Results: The article includes recommendations for prevention work and further research supplemented by comments of MOS and MOW staff.

Keywords: Recommendations, Prevention, Risky behaviours, Youth at-risk, Youth correctional centres
Wyniki: Badania pozwoliły na sformułowanie rekomendacji dla praktyki profilaktycznej oraz dalszych badań, które zostały przedstawione w pracy wraz z komentarzami pracowników MOS i MOW.

Słowa kluczowe: rekomendacje, profilaktyka, zachowania ryzykowne, młodzież z grup ryzyka, ośrodki socjoterapeutyczne, ośrodki wychowawcze

\section{- INTRODUCTION}

This article is a summary of a research project conducted among the students of youth sociotherapy centres (MOS) and youth correctional centres (MOW) in Poland. The research methodology and results in detail were presented in four articles published in this issue of the $\mathrm{Al}$ coholism and Drug Addiction quarterly. In this article, in addition to the summary of results, recommendations for preventive work and further research at MOS and MOW are proposed. These recommendations have been supplemented with comments from MOS and MOW staff collected during individual interviews, in which the interviewees commented on the results of surveys carried out among the students. The survey among the MOS/MOW students was supposed to: 1) assess the prevalence of psychoactive substance use and other problem and risky behaviours ${ }^{1}$ among MOS/MOW students, 2) characterise the problem/risky behaviour syndrome and 3) identify the psychosocial and behavioural risk and protective factors relevant to the emergence or reduction of problems arising from drinking alcohol. When commancing the project, we were aware that the intensity of problem/risky behaviours among the participants of our study is much greater than among teenagers in mainstream schools. Most of our participants were referred to special education institutions exactly because of their intense problem/risky behaviours. The significant prevalence of problems related to the use

1 The distinction between risky and problem behaviour was introduced by Richard Jessor, author of Theory of Problem/Risky Behaviours [1,2]. Problem behaviours are defined as inconsistent with generally accepted social norms meeting, as a consequence, social disapproval and sanction. Risky behaviours are defined as behaviours threatening the health and safety of young people.

\section{WPROWADZENIE}

Artykuł stanowi podsumowanie projektu badawczego zrealizowanego wśród podopiecznych młodzieżowych ośrodków socjoterapii (MOS) i młodzieżowych ośrodków wychowawczych (MOW) w Polsce. Metodologia tych badań oraz szczegółowe wyniki zostały zaprezentowane w czterech pracach opublikowanych $\mathrm{w}$ niniejszym numerze kwartalnika Alkoholizm i Narkomania. $\mathrm{W}$ tym artykule, obok podsumowania wyników, zamieszczono także propozycję rekomendacji dotyczących pracy profilaktycznej oraz dalszych badań w placówkach MOS i MOW. Rekomendacje te zostały opatrzone komentarzami przedstawicieli personelu MOS i MOW. Materiał zebrano podczas wywiadów indywidualnych, w ramach których rozmówcy wypowiadali się na temat wyników badań ankietowych wśród wychowanków. Badania wśród podopiecznych MOS/MOW miały na celu: 1) ocenę rozpowszechnienia używania substancji psychoaktywnych oraz innych zachowań problemowych i ryzykownych ${ }^{1}$ wśród młodzieży przebywającej w MOS i MOW, 2) charakterystykę syndromu zachowań problemowych/ryzykownych oraz 3) identyfikację psychospołecznych i behawioralnych czynników ryzyka i czynników chroniących, istotnych dla powstawania lub ograniczania problemów wynikających z picia alkoholu. Przystępując do realizacji projektu, zdawaliśmy sobie sprawę, że nasilenie zachowań problemowych/ryzykownych wśród uczestników naszych badań jest znacz-

\footnotetext{
${ }^{1}$ Rozróżnienie pomiędzy zachowaniami ryzykownymi i zachowaniami problemowymi zostało wprowadzone przez Richarda Jessora, autora teorii zachowań problemowych/ ryzykownych $[1,2]$. Zachowania problemowe są definiowane jako zachowania, które są niezgodne z przyjętymi ogólnie normami społecznymi i w konsekwencji spotykają się z dezaprobatą i sankcjami ze strony otoczenia. Zachowania ryzykowne definiowane są jako zachowania zagrażające zdrowiu i bezpieczeństwu młodych ludzi.
} 
of psychoactive substances and other mental health problems was also indicated by the results of previous study among juveniles MOS/MOW from Warsaw [3], as well as projects implemented in other institutions treating youth at risk of social maladjustment, such as voluntary labour corps, shelters for minors or youth custody centres [4]. Our study was a response to the unsufficient of empirical knowledge about problem and risky behaviours among young people at risk of social maladjustment and the factors preventing and conducing these behaviours.

\section{- PART I}

\section{SUMMARY OF RESEARCH RESULTS AMONG MOS AND MOW STUDENTS IN POLAND}

There were 64 randomly selected MOS and MOW centres in the study. Data of 1730 respondents were included in analyses. A detailed description of the research procedure and participant characteristics were presented in the introductory article [5].

\section{Use of psychoactive substances}

The results of the analyses indicate that, of the psychoactive substances, cigarettes and alcohol are the most widespread among MOS and MOW students. About $67 \%$ of respondents confirmed daily smoking, including about 59\% of the younger age group (12-15 years) and about $73 \%$ of the older (16-19 years) [6,7]. Smoking is more prevalent among young people at the MOW, especially daily smoking. However, no differences were found in the frequency of cigarette smoking between girls and boys [7]. The use of electronic cigarettes is much less common among MOS and MOW students. The percentage of daily e-cigarette users was about $10 \%$, with e-cigarettes more often used by MOS students and boys from the older nie większe niż wśród nastolatków uczących się w szkołach ogólnodostępnych. Większość naszych respondentów znalazła się w placówkach edukacji specjalnej właśnie z powodu nasilonych zachowań problemowych/ryzykownych. Na znaczne rozpowszechnienie problemów związanych z używaniem substancji psychoaktywnych oraz innych problemów zdrowia psychicznego wskazywały również wyniki wcześniejszych badań wśród wychowanków MOS/MOW z Warszawy [3] i projekty realizowane w innych instytucjach sprawujących pieczę nad młodzieżą zagrożoną niedostosowaniem społecznym, takich jak ochotnicze hufce pracy, schroniska dla nieletnich czy zakłady poprawcze [4]. Realizacja naszych badań stanowiła odpowiedź na niedostatek empirycznej wiedzy na temat zachowań problemowych i ryzykownych wśród młodych ludzi zagrożonych niedostosowaniem społecznym oraz czynników sprzyjających i przeciwdziałających występowaniu tych zachowań.

\section{- CZĘŚĆ I}

\section{PODSUMOWANIE WYNIKÓW BADAŃ WŚRÓD WYCHOWANKÓW MOS I MOW W POLSCE}

W badaniach wzięły udział 64 losowo dobrane placówki MOS i MOW, a analizami objęto dane zebrane od 1730 respondentów. Szczegółowy opis przebiegu badań i charakterystyka ich uczestników zostały zamieszczone w artykule wprowadzającym [5].

\section{Używanie substancji psychoaktywnych}

Wyniki przeprowadzonych analiz wskazują, że spośród substancji psychoaktywnych najbardziej rozpowszechnione wśród wychowanków MOS i MOW są papierosy i alkohol. Około $67 \%$ badanych uczniów potwierdziło, że codziennie pali papierosy, w tym ok. 59\% z młodszej grupy wiekowej (12-15 lat) i ok. $73 \% \mathrm{z}$ grupy starszej (16-19 lat) [6, 7]. Palenie tytoniu jest bardziej rozpowszechnione wśród młodzieży z MOW, zwłaszcza palenie codzienne. Nie stwierdzono natomiast różnic $\mathrm{w}$ częstości palenia papierosów pomiędzy dziewczętami i chłopcami [7]. Korzystanie z papierosów elektronicznych jest znacznie mniej rozpowszechnione wśród podopiecznych MOS i MOW. Odsetek codziennych użytkowników e-papierosów wynosił ok. 10\%, przy czym po e-papierosy częściej sięga młodzież z MOS i chłopcy ze starszej grupy 
age group. The vast majority of MOS and MOW students have experimented with drinking alcohol [7]. Frequent drinking, i.e. in the last 30 days, was confirmed by about $48 \%$ of the students from the younger age group and $56.5 \%$ from the older, while about $39 \%$ of the younger participants and $45 \%$ of the older reported frequent drunkenness. In addition, it turned out that drinking and getting drunk in the last 30 days is significantly more common among girls and MOS students. In contrast, the rates of drinking alcohol and getting drunk in the last year were higher among MOW students [7]. As may be supposed, this result is related to the specificity of the functioning of both these institutions. In MOS, students study like at regular school and take advantage of extra-classes but not all MOS provide 24-hour care as in some of them, students return home after classes. MOW students are permanently housed in boarding centres and may only leave with court consent. For this reason, at least some MOS students may have easier access to alcohol on a daily basis and use it more often [7].

Illegal drug use is prominent among the risky behaviors of MOS and MOW students, of who $63.5 \%$ of the younger and $75 \%$ of the older respondents used such drugs at least once in the year prior to the study. The most commonly mentioned drugs were cannabis, amphetamines, ecstasy/MDMA and new psychoactive substances (NPS), so called "boosters", as well as mephedrone, which is included in the NPS, but because of its high prevalence, was mentioned in the survey as a separate substance. A large group of respondents (18.5\% younger and $24 \%$ older), took psychotropic and sedative medicines as well as sleeping pills. In addition, a significant percentage of respondents (38\% younger and $43 \%$ older) reported frequent use of marijuana or hashish, while NPS were often taken by $13.5 \%$ of both younger and older study participants [7].

The analyses indicate that MOS and MOW students use psychoactive substances much more often than their mainstream school peers, only the data on the percentage who drink and smoke traditional cigarettes was similar to the regular school results. In sum, MOS and MOW students reported a much higher incidence of drunkenness, daily smoking of traditional cigarettes, use of cannabis, amphetamine, cocaine, ecstasy/MDMA and NPS [7]. wiekowej. Zdecydowana większość wychowanków MOS i MOW ma za sobą próby picia alkoholu [7]. Częste picie alkoholu, czyli sięganie po alkohol w ostatnich 30 dniach, potwierdziło ok. $48 \%$ badanych uczniów z młodszej grupy wiekowej i 56,5\% ze starszej grupy wiekowej. Natomiast częste upijanie się raportowało ok. 39\% młodszych i 45\% starszych uczestników. Ponadto okazało się, że picie alkoholu i upijanie się w ostatnich 30 dniach jest istotnie częstsze wśród dziewcząt oraz młodzieży z MOS. Wskaźniki picia alkoholu i upijania się w ostatnim roku były natomiast wyższe wśród podopiecznych MOW [7]. Jak można przypuszczać, wynik ten jest związany ze specyfiką działania obu tych placówek. W MOS wychowankowie uczą się w szkole i korzystają $\mathrm{z}$ zajęć dodatkowych, ale nie wszystkie $\mathrm{z}$ tych placówek zapewniają opiekę całodobową - w przypadku niektórych MOS uczniowie po zakończeniu zajęć wracają do domów. Natomiast podopieczni MOW stale przebywają $\mathrm{w}$ ośrodkach $\mathrm{z}$ internatem i mogą je opuszczać jedynie za zgodą sądu. $Z$ tego względu młodzież z MOS, przynajmniej w części z tych placówek, może mieć na co dzień łatwiejszy dostęp do alkoholu i sięgać po niego częściej [7].

Wśród zachowań ryzykownych wychowanków MOS i MOW istotne miejsce zajmuje używanie narkotyków. Po tego rodzaju substancje sięgało przynajmniej raz w ostatnim roku przed badaniem $63,5 \%$ młodszych i $75 \%$ starszych respondentów. Najpowszechniej wymienianymi narkotykami były przetwory konopi, amfetamina, ecstasy/MDMA i nowe substancje psychoaktywne (NSP), czyli tzw. dopalacze, a także mefedron, który jest zaliczany do NSP, ale $z$ powodu znacznego rozpowszechnienia był wymieniony $\mathrm{w}$ ankiecie jako osobna substancja. Liczna grupa badanych - 18,5\% młodszych oraz $24 \%$ starszych - przyjmowała leki psychotropowe, uspokajające i nasenne. Ponadto znaczny odsetek badanych (38\% młodszych oraz $43 \%$ starszych) raportował częste używanie marihuany i/lub haszyszu, a po NSP sięgało często $13,5 \%$ zarówno młodszych, jak i starszych uczestników badań [7].

Przeprowadzone analizy wskazują, że wychowankowie MOS i MOW sięgają po substancje psychoaktywne znacznie częściej niż ich rówieśnicy ze szkół ogólnodostępnych, jedynie dane dotyczące odsetków uczniów pijących alkohol i sięgających po tradycyjne papierosy były zbliżone do wyników w populacji młodzieży uczęszczającej do zwykłych szkół. Podsumowując, wśród podopiecznych MOS i MOW zaobserwowano znacznie wyższe rozpowszechnienie upijania się, codziennego palenia tradycyjnych papierosów, używania przetworów konopi, amfetaminy, kokainy, ecstasy/ MDMA oraz NSP [7]. 


\section{Other problem/risky behaviour}

Apart from using psychoactive substances, MOS and MOW students also reported numerous forms of anti-social behaviour. Over $40 \%$ admitted that, in the last year, they had often ( 3 or more times) lied to others to gain or avoid something and had had problems with the police. About a third of the participants had directed verbal aggression towards their teachers/guardians, carried dangerous tools (knives, brass knuckles) and participated in shoplifting. Behaviours such as selling marijuana or other drugs, escaping from a home or centre, and fighting were also widespread. It is also worth emphasising that about $25 \%$ confirmed engaging in risky sexual behaviour - i.e. having had 3 or more partners in their sexual careers [6].

Most of the antisocial behaviours had been performed more often by boys, while more girls reported that they had resorted to verbal aggression towards teachers/guardians and lying. In addition, girls are more likely to run away from home or a centre. As you can suppose, this is the result of socialisation forms that teach girls "escape" or "avoidance" problem solving strategies [6].

\section{Risky behaviour syndrome}

The analyses allowed us to conclude that the studied sample is diversified in terms of manifestations of problem behaviour syndrome - i.e. the co-occurrence of various problem/risky behaviours. Most, that is $80 \%$ of MOS and MOW students manifest a more or less "saturated" syndrome as only in the case of $20 \%$ were single or problematic risk behaviours recorded. Analyses of its structure indicate that there are two highly correlated factors making up the problem/risky behaviour syndrome. In the case of the first, unlawful and aggressive behaviours dominated together with cyberbullying and gambling, and in the case of the second, characteristic was the use of psychoactive substances, which was accompanied by risky sexual behaviour [6].

\section{Inne zachowania problemowe/ryzykowne}

Wychowankowie MOS i MOW, oprócz używania substancji psychoaktywnych, potwierdzali także podejmowanie licznych zachowań antyspołecznych. Ponad $40 \%$ uczestników badanych przyznało się, że w ostatnim roku często (tj. 3 lub więcej razy) okłamało innych w celu uzyskania bądź uniknięcia czegoś oraz miało problemy z policją. Około jedna trzecia uczestników badań stosowała agresję werbalną wobec swoich nauczycieli/opiekunów, nosiła ze sobą niebezpieczne narzędzia (noże, kastety) i uczestniczyła w kradzieżach sklepowych. Znacznie rozpowszechnione były również takie zachowania, jak sprzedaż marihuany lub innych narkotyków, ucieczki z domu lub ośrodka i bójki. Warto też podkreślić, że ok. 25\% potwierdziło podejmowanie ryzykownych zachowań seksualnych, tzn. miało w życiu 3 lub więcej partnerów seksualnych [6].

Większość zachowań antyspołecznych, o które pytano w ankiecie, częściej podejmują chłopcy. Natomiast dziewczęta częściej niż chłopcy potwierdzały, że uciekają się do agresji werbalnej wobec nauczycieli/opiekunów i okłamywania innych. Ponadto dziewczęta częściej uciekają z domu lub ośrodka. Jak można przypuszczać, jest to efekt zabiegów socjalizacyjnych, podczas których dziewczęta uczone są „ucieczkowych” lub „unikowych” strategii rozwiązywania problemów [6].

\section{Syndrom zachowań ryzykownych}

Przeprowadzone analizy pozwoliły stwierdzić, że badana próba jest zróżnicowana pod względem przejawów syndromu zachowań problemowych, czyli współwystępowania różnych zachowań problemowych/ryzykownych. Większość, tj. 80\%, podopiecznych MOS i MOW przejawia mniej lub bardziej „nasycony” syndrom tych zachowań; jedynie w przypadku $20 \%$ odnotowano występowanie pojedynczych zachowań problemowych/ryzykownych lub ich brak. Analizy dotyczace struktury tego syndromu wskazują, że można mówić o dwóch wysoko skorelowanych czynnikach składających się na syndrom zachowań problemowych/ryzykownych. W przypadku pierwszego z tych czynników dominowały zachowania sprzeczne $\mathrm{z}$ prawem i zachowania agresywne, razem $z$ cyberprzemocą oraz uprawianiem hazardu, w przypadku drugiego czynnika charakterystyczne było używanie substancji psychoaktywnych, któremu towarzyszyły ryzykowne zachowania seksualne [6]. 


\section{Risk and protective factors related to alcohol} use

MOS and MOW students grow up in high-risk families and environments characterised by a constellation of many risk factors affecting the child and the whole family together with a scarcity of protective factors. This research project was mainly focused on the issue of drinking so analyses of risk and protective factors referred mainly to alcohol consumption. The results indicate that the strongest risk factors determining the frequency of drinking, getting drunk and experiencing alcohol-related problems were:

- attempted suicide in the past,

- need for sensation seeking,

- impulsiveness,

- teenage subjective norms conducive to drinking alcohol and the use of other psychoactive substances, in other words, the respondent's own belief that $\mathrm{s} / \mathrm{he}$ is free to use them,

- positive peer relationships,

- use of alcohol and other psychoactive substances by close friends and the non-familial adults[8].

An important protective factor turned out to be parental control of a teenager's free time as well as daily participation in such forms of spending free time like computer games and regular, weekly participation in organised extracurricular activities (other than sports). At the same time, factors related to the forms of spending free time were associated with less frequent alcohol use but were not significantly associated with getting drunk and experiencing alcohol-related problems [8].

\section{- PART II}

\section{RECOMMENDATIONS}

The results of the study allowed us to formulate recommendations for preventive work with MOS and MOW students. As mentioned in the introduction, these recommendations have been commented on by MOS and MOW staff participating in the individual interviews. The purpose of these interviews was to get interviewees' opinions on the survey results presented in the summary report. Detailed interview questions concerned this report form and content. The interviewees were

\section{Czynniki ryzyka i czynniki chroniące warunkujące picie alkoholu}

Podopieczni MOS i MOW to młodzież dorastająca $\mathrm{w}$ rodzinach oraz środowiskach podwyższonego ryzyka, które charakteryzują się konstelacją wielu czynników ryzyka oddziałujących na dziecko i całą rodzinę, przy jednoczesnym niedostatku czynników chroniących. Ze względu na to, że niniejszy projekt badawczy był skoncentrowany głównie na problematyce picia alkoholu, analizy dotyczące czynników ryzyka i czynników chroniących odnosiły się właśnie do tej kwestii. Ich wyniki wskazują, że najsilniejszymi czynnikami ryzyka, warunkującymi częstość picia alkoholu, upijania się i doświadczanie problemów związanych z alkoholem, były:

- podejmowane w przeszłości próby samobójcze,

- zapotrzebowanie na stymulację,

- impulsywność,

- subiektywne normy nastolatka sprzyjające piciu alkoholu i używaniu innych substancji psychoaktywnych, innymi słowy: własne przekonanie badanego, że wolno mu sięgać po te substancje,

- pozytywne relacje z rówieśnikami,

- używanie alkoholu i innych substancji psychoaktywnych przez bliskich kolegów oraz znajomych dorosłych spoza rodziny [8].

Istotnym czynnikiem chroniącym okazała się kontrola rodzicielska czasu wolnego nastolatka, a także codzienne uczestniczenie $\mathrm{w}$ takich formach spędzania czasu wolnego, jak gry komputerowe i regularny, cotygodniowy udział w zorganizowanych zajęciach pozalekcyjnych (innych niż sportowe), przy czym czynniki odnoszące się do form spędzania czasu wiązały się z rzadszym sięganiem po alkohol, ale nie miały istotnego związku z upijaniem się oraz doświadczaniem problemów związanych $\mathrm{z}$ piciem alkoholu [8].

\section{- CZĘŚĆ II}

\section{REKOMENDACJE}

Wyniki przeprowadzonych badań pozwoliły na sformułowanie rekomendacji do pracy profilaktycznej z wychowankami MOS i MOW. Jak już wspomniano we wprowadzeniu, rekomendacje te opatrzono komentarzami przedstawicieli personelu MOS i MOW - uczestników wywiadów indywidualnych. Celem tych wywiadów było poznanie opinii rozmówców na temat wyników badań ankietowych zaprezentowanych $\mathrm{w}$ raporcie podsumowującym. Szczegółowe pytania wywiadu dotyczyły treści oraz 
asked, among others, whether the research results and recommendations would be useful for preventive work in MOS and MOW.

Individual interviews were conducted with staff of 10 MOS and 10 MOW centres (including directors, teachers, psychologists and educators). Of the 20 participants, there were 13 women. The conversations were carried out over phone, recorded with the interviewees' consent and transcribed. The thematic analysis method was used to analyse the collected information [9].

\section{Recommendations for preventive work at MOS and MOW}

1. The use of psychoactive substances among MOS and MOW students has turned out to be, as in the general youth population, one of the leading problem/risky behaviours. Therefore, elements of harm reduction are recommended instead of focusing on education on the harmful effects of psychoactive substances. Most MOS and MOW students have already initiated substance use and largely display the harmful patterns of their use as confirmed by this interviewee:

[Young people have already been initiated into using] psychoactive substances (...) these are illegal drugs, as well as alcohol and cigarettes. We cannot avoid it. The e-cigarette is also in fashion. We talk about the harmfulness of drugs of all kinds, including boosters [NPS] and alcohol. The young people here know their stuff in this area. Also, we organise workshops with external speakers. But we are not able to avoid certain behaviours (...) that's just what it's like (...) There is lack of discussion about what the students would do to protect themselves. (MOS_pedagogist)

2. It can be assumed that drinking and using other psychoactive substances among MOS/ MOW students may not only have a social aspect but also serve to reduce negative emotions related to mental health problems. This is indicated by the relationship between alcohol use and suicide attempts. Therefore, MOS/MOW students' mental health should be the subject of concern and particularly intensive activities. The importance of actions aimed at supporting mental health was also emphasised by interview participants: formy raportu. Rozmówcy byli pytani m.in. o to, czy rezultaty badań i sformułowane na ich podstawie rekomendacje będą przydatne w pracy profilaktycznej w MOS i MOW.

Przeprowadzono wywiady indywidualne z przedstawicielami 10 placówek MOS i 10 MOW (w tym z dyrektorami, pedagogami, psychologami i wychowawcami). W wywiadach wzięło udział 20 osób - 13 kobiet i 7 mężczyzn. Rozmowy zostały przeprowadzone przez telefon, za zgodą rozmówców nagrane, a następnie spisane. Do analizy zebranych informacji zastosowano metodę analizy tematycznej [9].

\section{Rekomendacje dotyczące pracy profilaktycznej w MOS i MOW}

1. Używanie substancji psychoaktywnych wśród wychowanków MOS i MOW, podobnie jak w populacji ogólnej młodzieży, okazało się jednym $\mathrm{z}$ wiodących zachowań problemowych/ryzykownych. W związku z tym rekomendowane są elementy redukcji szkód w miejsce skupiania się na edukacji dotyczącej szkodliwości substancji psychoaktywnych. Podopieczni MOS i MOW w większości są już po inicjacji i w dużej mierze przejawiają szkodliwe wzory używania tych substancji. Potwierdzali to nasi rozmówcy:

[Młodzież jest po inicjacji w używaniu] środków psychoaktywnych (...) sa to narkotyki, jak również alkohol i papierosy. Tego nie jesteśmy w stanie uniknać. Modny jest też e-papieros. My dzieciom ttumaczymy, mówimy o szkodliwości zarówno narkotyków wszelkiego rodzaju, w tym dopalaczy, jak i alkoholu. Młodzież tutaj ma pojęcie, ma wiedzę w tym zakresie. Dodatkowo organizujemy warsztaty, na które przyjeżdzaja do nas ludzie z zewnątrz. Ale nie jesteśmy $w$ stanie uniknać pewnych zachowań naszych wychowanków, (...) taka jest prawda, a nie inna (...). Brakuje tutaj [poruszenia kwestii], co by oni zrobili, czyli wyciagnięcia od młodzieży, co by oni zrobili, żeby uchronić siebie. (MOS_pedagog)

2. Można przypuszczać, że wśród młodzieży z MOS/MOW picie alkoholu i używanie innych substancji psychoaktywnych może mieć nie tylko towarzyski charakter, lecz także służyć ograniczaniu negatywnych emocji związanych z problemami w obszarze zdrowia psychicznego. Wskazuje na to związek pomiędzy sięganiem po alkohol a próbami samobójczymi. Z tego względu zdrowie psychiczne podopiecznych placówek MOS i MOW powinno być przedmiotem troski i szczególnie intensywnych działań. Znaczenie działań ukierunkowanych na wspieranie zdrowia psychicznego wychowanków podkreślali również uczestnicy wywiadów: 
A very important issue (...) that also came out in our internal research that in addition to substance use there is the issue of mood disorders (...) So, on average, $30 \%$ of respondents report issues related to mood swings towards depressive disorders. It's nice that this area was also touched on here (...) not only the issues related to substance use, which are very often the effects of other, deeper problems. (MOW_psychologist)

Students' mental health is a general priority (...). It seems to me that this is also changing in us, that we are more sensitive to sad children, to children who are wandering around the place. We're starting to pay attention to this. (MOW_pedagogist)

3. Among individual factors, self-control was found to be important in reducing drinking-related problems. This factor can be modified in therapeutic or preventive work with at-risk youth, by extending the offer of workshops with trainings focused on improving this skill [10]. The need to conduct of this kind of activities was also confirmed by our interviewees:

[We conduct] self-esteem raising workshops and that support a sense of agency. That I have control over events and that I can influence what is happening. [Therefore, it is important] to expand the offer of workshops improving interpersonal skills. (MOW_psychologist)

In the context of work on self-control, the interviewees pointed out the difficulties associated with the occurrence of neurological problems in some students:

We have children who have not been fully diagnosed in various respects like epilepsy or other neurological problems. And those self-control trainings that we provide as teachers, specialists, educators, i.e. encouraging the pursuit of goals, setting short and long-term objectives or supporting independence, which also affects the management of our emotions, this is a very difficult and bumpy road whose effects [can be seen years later]. (...) Or [these effects] can be the results of various factors, biological and maturation and our treatment. (MOW_pedagogist)
Bardzo ważna kwestia (...) i to też wyszło w naszych wewnętrznych badaniach, że opróczzachowań ryzykownych, zwiazanych $z$ używaniem substancji, jest kwestia zaburzeń nastroju. (...) Tak średnio 30\% ankietowanych zgłasza kwestie zwiąane z labilnościa nastroju, ale $w$ stronę zaburzeń depresyjnych. Fajnie, że tutaj takize ten obszar został poruszony (...) nie tylko same kwestie zwiazane $z$ używaniem substancji, które bardzo często sq skutkami innych, głębszych problemów. (MOW_psycholog)

Zdrowie psychiczne podopiecznych to $w$ ogóle priorytet (...). Wydaje mi się, że to też się zmienia u nas, jeśli chodzi o kadrę, że jesteśmy bardziej wyczuleni na dzieci smutne, na dzieci, które snują się po katach, zwracamy na to uwage. (MOW_pedagog)

3. Spośród czynników indywidualnych istotne znaczenie w ograniczaniu problemów wynikających z picia alkoholu okazała się mieć samokontrola. Czynnik ten można modyfikować $\mathrm{w}$ pracy terapeutycznej czy profilaktycznej z młodzieżą zagrożoną, poprzez poszerzanie ofert zajęć o treningi ukierunkowane na doskonalenie tej umiejętności [10]. Potrzebę prowadzenia takich zajęć potwierdzali także nasi rozmówcy:

[Prowadzimy] zajęcia budujące samoocene i dające poczucie sprawstwa, że mam nad czymś kontrole i to ja moge wplywać na to, co sie dzieje. [Dlatego ważne jest] poszerzenie oferty warsztatów doskonalących umiejętności interpersonalne. (MOW_psycholog)

W kontekście pracy nad samokontrolą uczestnicy wywiadów zwrócili jednak uwagę na trudności związane z występowaniem u części wychowanków problemów neurologicznych:

Trafiaja do nas dzieci nie do końca zdiagnozowane pod różnymi względami, padaczki czy innych problemów neurologicznych. I te treningi samokontroli, o które my dbamy jako wychowawcy, specjaliści, pedagodzy, czyli zachęcanie do dążenia do celu, wyznaczanie tych celów krótko-i dlugoterminowych czy wspieranie ich niezależności, co też wpływa na zarzadzanie własnymi emocjami, to jest bardzo trudna $i$ wyboista droga, której efekty [można zobaczyć po latach]. (...) Albo [te efekty] moga być wypadkowa różnych czynników, dojrzewania biologicznego, naturalnego oraz naszych zabiegów. (MOW_pedagog) 
4. Our study results indicate the importance of sensation seeking as risk factor associated with alcohol use and experincing alcohol related problems. The need for intense and exciting experiences may also lead to many other risky behaviours, including the use of other psychoactive substances, aggression and crime $[3,10-$ 13]. Therefore in educational and preventive work with young people, it is worth providing attractive and constructive forms of leisure time activities. This strategy is particularly effective in the case of high risk adolescents like those at MOS and MOW. Leisure time activities should be intensive and conducted regularly, as well as respond to students' needs. The importance of offering activities focused on satisfying the need for stimulation was also emphasised by the interview participants:

For us it is important and it is also consistent with the recommendations from our research that at the root of drinking and psychoactive substance use, is sensation seeking - the need for stimulation. (...) Therefore [we run] various types of activities that provide the right amount of stimuli. (MOW_psychologist)

It was also noted that one of the criteria for employment in centres is the opportunity for the educators to meet these needs of those in their care:

As for these intense and very regular activities that meet the needs of the students. This is also, among other things, a condition for selecting staff for the MOW, at least in my centre. (MOW_pedagogist)

Unfortunately, a lack of funds is a barrier for providing young people with attractive and constructive leisure time activities:

We have no money, neither for the theater, nor even for swimming pool activities. (...). Buying crayons for children is a problem, let alone take them to the theater or a climbing wall, which would be more interesting for them than theater (...). They rarely go on trips because we don't have a bus. (...) Maybe other local communities are richer? (MOS_director)

5. The impact of parental support on reducing adolescent risky behaviour has been documented
4. Wyniki badań wskazują na istotne znaczenie poszukiwania wrażeń jako czynnika ryzyka sprzyjającego piciu alkoholu i doświadczaniu związanych z tym problemów. Potrzeba silnych i ekscytujących doświadczeń może również skłaniać do podejmowania wielu innych zachowań ryzykownych, w tym używania innych substancji psychoaktywnych, agresji, łamania prawa [3, 10-13]. Z tego względu w pracy wychowawczo-profilaktycznej z młodzieżą warto zadbać o ofertę atrakcyjnych i konstruktywnych form spędzania czasu. Strategia ta jest szczególnie skuteczna $\mathrm{w}$ przypadku młodzieży $\mathrm{z}$ grup podwyższonego ryzyka, takich jak wychowankowie MOS i MOW. Zajęcia dla podopiecznych tych placówek powinny być intensywne i prowadzone regularnie, a także odpowiadać na potrzeby wychowanków. Znaczenie oferty zajęć ukierunkowanych na zaspokojenie potrzeby stymulacji podkreślali także uczestnicy wywiadów:

Dla nas jest ważne i jest też zbieżne $z$ rekomendacjami $z$ naszych badań, że u podłoża picia, sięgania po środki psychoaktywne leży poszukiwanie wrażeń, potrzeba stymulacji. (...) Dlatego [prowadzimy] różne rodzaje zaję́, które dostarczaja odpowiedniej ilości bodźców. (MOW_psycholog)

Zwrócono także uwagę, że jednym z kryteriów zatrudnienia w ośrodkach jest możliwość sprostania przez wychowawcę tym potrzebom podopiecznych:

Jeśli chodzi o te intensywne i bardzo regularne zajęcia, które odpowiadaja na potrzeby wychowanków. To jest też, między innymi, warunek doboru kadry do MOW, przynajmniej w mojej placówce. (MOW_pedagog)

Niestety barierą w zapewnieniu wychowankom atrakcyjnych i konstruktywnych form spędzania czasu jest brak funduszy:

My nie mamy pieniędzy ani na teatr, ani nawet na basen dla dzieci. (...) To jest problem, żeby kredki dzieciom kupić, a co dopiero zabrać do teatru albo na ściankę wspinaczkowa, co byłoby dla nich ciekawsze niż teatr (...). Bardzo rzadko jeżdża na wycieczki, bo nie mamy na autobus. (...) Może inne gminy sq bardziej bogate? (MOS_dyrektor)

5. Wpływ wsparcia rodziców na ograniczanie zachowań ryzykownych młodzieży został udokumen- 
in many studies, some of which have been conducted in Poland [14]. However, the data obtained in this project indicate that, in the case of MOS and MOW students, parental support is not a significant protective factor, at least not in relation to drinking. On the other hand, this does not mean that the family environment has no impact on the reduction of alcohol consumption by those in care. The study revealed that an important protective factor is parental control over how young people spend their free time. Therefore including parents in preventive activities targeting students and expanding the offer of workshops that develop parental skills is a promising course of action [15]. Social assistance or other forms of support for families in a difficult financial, health or legal situation would also be useful. However, this requires systemic solutions. In our interviewees opinion, one of the barriers to cooperation with parents is limited contact with them, sometimes caused by a lack of money:

We do not have much contact with parents (...) [it] is very limited because we have children from all over Poland, so this is only a very occasional contact, usually by phone. Often we do not see these parents at all. (MOS_director)

There is always the money issue, but there is also the problem of getting to the site itself. You have to change from one bus to another to get there. (MOW_psychologist)

6. As young people mature, peers have a particular influence on adolescent behaviour; many studies indicate that young people are more likely to use psychoactive substances if they are convinced that this behaviour is widespread and accepted by peers [14, 16-18]. Our study confirmed that those MOS and MOW students who more frequently drink and abuse alcohol and also experience related problems, are also those who judge that many of their close friends use psychoactive substances. Beliefs regarding the prevalence and degree of social approval for the use of these substances are the basis for creating subjective norms for drinking alcohol; subjective norms have been shown to be one of the strongest risk factors associated with alcohol consumption. Students who think they are free to use psychoactive towany w wielu badaniach, również przeprowadzonych w Polsce [14]. Dane uzyskane w tym projekcie wskazują natomiast, że w przypadku wychowanków MOS i MOW wsparcie ze strony rodziców nie jest znaczącym czynnikiem chroniącym - przynajmniej $\mathrm{w}$ odniesieniu do picia alkoholu. Nie oznacza to jednak, że środowisko rodzinne nie ma wpływu na ograniczenie picia alkoholu przez podopiecznych tych placówek. Okazuje się bowiem, że istotnym czynnikiem chroniącym jest kontrola rodziców dotycząca tego, w jaki sposób młodzież spędza wolny czas. Włączenie rodziców do działań profilaktycznych adresowanych do wychowanków i poszerzanie oferty warsztatów doskonalenia umiejętności wychowawczych jest więc obiecującym kierunkiem działań [15]. Przydatna byłaby także pomoc socjalna bądź inne formy wsparcia dla rodzin, które mają trudną sytuację materialną, zdrowotną lub prawną. Wymaga to jednak rozwiązań systemowych. W opinii naszych rozmówców jedną z barier we współpracy jest ograniczony kontakt $\mathrm{z}$ rodzicami, spowodowany niekiedy brakiem pieniędzy:

Nie mamy bardzo dużego kontaktu z rodzicami (...). [jest] bardzo ograniczony $z$ tego względu, że mamy dzieci z całej Polski, więc jest to kontakt bardzo okazjonalny, najczęściej telefoniczny, często tych rodziców na oczy nie widzimy. (MOS_dyrektor)

To jest zawsze problem pieniędzy, ale jest też i problem samego dotarcia do ośrodka. To jest problem, że trzeba się przesiąść $w$ dwa busy i dojechać. (MOW_ psycholog)

6. W okresie dojrzewania szczególny wpływ na zachowanie nastolatków mają rówieśnicy; wiele badań wskazuje, że młodzi ludzie są bardziej skłonni sięgać po substancje psychoaktywne, jeśli są przekonani, że takie zachowania są powszechne i akceptowane przez rówieśników [14, 16-18]. Przeprowadzone badania potwierdziły, że częściej piją i nadużywają alkoholu, a także doświadczają związanych $\mathrm{z}$ tym problemów ci wychowankowie MOS i MOW, którzy sądzą, iż wiele bliskich koleżanek i kolegów używa substancji psychoaktywnych. Przekonania dotyczące rozpowszechnienia i stopnia społecznej aprobaty dla używania tych substancji są podstawą tworzenia subiektywnych norm dotyczących picia alkoholu; subiektywne normy okazały się jednym z najsilniejszych czynników ryzyka powiązanych z piciem alkoholu. Wychowankowie, którzy sądzą, 
substances were more likely to use alcohol. Conversely, a student's belief that he or she must not use these substances reduced the risk of drinking and abusing alcohol. In this context, it is recommended that measures based on normative education strategies are included in preventive MOS and MOW programmes based on strengthening norms that prevent the use of psychoactive substances by young people. The importance of normative education was also emphasised by the participants :

[The interesting] conclusion is about subjective norms (...) to work on morality in the broad sense, on these norms, what is good and what is not good. (...) Always refer to these norms; why others may follow other norms, and where such norms come from in society. (MOS_psychologist)

7. Taking care of the good social climate of educational institutions is an important strategy in preventive and resocialisation work. A positive climate is conducive to proper socialisation and is an important factor protecting young people from risky/problem behaviour [19]. A positive social climate is therefore a factor that should be taken into account in the MOS and MOW work system. This was confirmed by the participants, who also pointed to the threats to the institutions' social atmoshere stemming from the student's environment of origin:

With us, if we manage to create a nice climate in the centre, then the problems actually decrease automatically. The problems start when the boys go on home leave. They return to their original environment, which works rather like knocking down a protruding nail. Having learned something at the centre, he changed his habits a bit and returns to his environment. He will stay for two weeks and return as a "reset" young man with the environmental norms having worked in a destructive way. (MOW_ psychologist)

8. The study has confirmed that positive relationships with peers increase the risk of alcohol abuse and the severity of alcohol-related problems. This result is not surprising given that young people's drinking is associated with popularity, social status and more friends [20-22]. że wolno im używać substancji psychoaktywnych, byli bardziej skłonni sięgać po alkohol. I odwrotnie, przekonanie wychowanka, że nie wolno mu używać tych substancji, zmniejszało ryzyko picia i nadużywania alkoholu. W tym kontekście do programów profilaktycznych w MOS i MOW rekomendowane jest włączenie działań opartych na strategii edukacji normatywnej, która polega na wzmacnianiu norm przeciwnych używaniu przez młodzież substancji psychoaktywnych. Znaczenie edukacji normatywnej podkreślali także uczestnicy wywiadów:

[Ciekawy jest] wniosek dotyczacy subiektywnych norm (...), żeby jednak pracować nad moralnościa szeroko pojęta, nad tymi normami, co jest dobre, co nie jest dobre. (...) Cały czas się odnosić do tych norm, dlaczego inni moga wyznawać inne normy, skad to sie bierze, skad takie normy w społeczeństwie. (MOS_psycholog)

7. Ważną strategią w pracy profilaktyczno-resocjalizacyjnej z młodzieżą jest dbanie o dobry klimat społeczny placówek edukacyjnych. Pozytywny klimat sprzyja prawidłowej socjalizacji i stanowi istotny czynnik chroniący młodzież przed podejmowaniem zachowań ryzykownych/ problemowych [19]. Pozytywny klimat społeczny to zatem czynnik, który należy wziąć pod uwage w systemie pracy MOS i MOW. Potwierdzali to uczestnicy wywiadów, wskazując jednocześnie na zagrożenia dla klimatu społecznego placówek wychowawczych związane ze środowiskiem, z którego wywodzą się wychowankowie:

U nas to jest tak, że jeżeli udaje nam się stworzyć fajny klimat w placówce, to problemy faktycznie automatycznie się obniżaja. Problemy pojawiaja sie wtedy, gdy chłopcy jeżdza na przepustke. Wracaja do środowiska, które działa na zasadzie wbijania wystającego gwoździa. W ośrodku czegoś się nauczyl, zmienit w pewnym stopniu swoje nawyki, a wraca do swojego środowiska. Pobędzie tak dwa tygodnie i wraca "zresetowany" młody człowiek, bo tamtejsze normy środowiskowe zadziałały $w$ destruktywny sposób. (MOW_psycholog)

8. Przeprowadzone badania potwierdziły, że pozytywne relacje $\mathrm{z}$ rówieśnikami zwiększają ryzyko nadużywania alkoholu i nasilenia problemów, które są następstwem sięgania po alkohol. Wynik ten nie jest zaskakujący, biorąc pod uwagę, że picie alkoholu 
Therefore the introduction of programmes the goal of which would the creation and support of peer groups with positive goals is recommended. In our interviewees' opinion, the difficulty in implementing this recommendation is that young people who can "boast" a rich past in breaking existing standards, play the role of leaders in the centres:

Certainly, every MOW or MOS practitioner makes sure that the programmes are based on peer groups, supporting leaders with these [desirable] qualities. But it often has nothing to do with the [realities] (...). I know that in our MOW there is a tendency to stay in touch with peers, but rather with those strong ones who are actually the informal, though not necessarily positive leaders. (MOW_pedagogist)

Including students in activities outside the centres tends, in turn, to be hindered by local people's prejudices:

This is a valuable suggestion that they should be included in youth groups with positive goals. (...) We have tried; one boy goes to soccer at the club, another goes to the fire brigade volunteers - he was once an altar boy. But these are exceptions to the rule. When we wanted to send two, there were problems. It's a good thing but we just have no idea how to do it, how to deal with these prejudices. I also understand these parents, if someone has children, they want to protect them against these [negative influences]. In the city it is a little easier to blend in the environment. (MOW_psychologist)

9. The results of our analyses indicate a large internal variation of MOS/MOW students' problems and needs. Students from these institutions display the entire intensity spectrum of problem/risky behaviours - from individual behaviours to a very complex syndrome of risk behaviours. In order to respond more adequately to the needs of such a diverse group, greater specialisation within a system of educational/sociotherapeutic centres is required. Specialisation of the centres could concern, on the one hand, youth at risk of social maladjustment, which primarily demonstrates increased anti-social behaviour (offences, violence, gambling), and przez młodych ludzi wiąże się z popularnością i pozycją w grupie społecznej oraz większą liczbą przyjaciół [20-22]. Z tego względu rekomendowane jest wprowadzenie programów, których celem byłoby tworzenie i wspieranie grup rówieśniczych o pozytywnych celach. W opinii naszych rozmówców utrudnieniem $\mathrm{w}$ realizacji tej rekomendacji jest to, że funkcję liderów w ośrodkach pełnią młodzi ludzie, którzy mogą „pochwalić się" bogatą przeszłością w łamaniu obowiązujących norm:

Na pewno każdy praktyk w MOW czy w MOS bardzo mocno dba o to, zeby programy byly oparte o grupy rówieśnicze, na wspieraniu liderów o tych [pożądanych] cechach. Ale niejednokrotnie to się nijak ma do [realiów] (...). Ja wiem, że u nas $w$ MOW jest ta tendencja do utrzymywania relacji $z$ rówieśnikami, ale raczej tymi silnymi, którzy tak naprawdę sa liderami nieformalnymi, niekoniecznie pozytywnymi. (MOW_pedagog)

Włączanie wychowanków do zajęć prowadzonych poza ośrodkiem napotyka $\mathrm{z}$ kolei barierę $\mathrm{w}$ postaci uprzedzeń mieszkańców środowiska lokalnego:

To jest cenna wskazówka, że oni powinni być właczani do grup młodzieży o pozytywnych celach. (...) Podejmowaliśmy takie próby, jeden chłopiec chodzi na piłkę nożna do klubu, inny chodzi do OSP, kiedyś byt ministrantem. Ale to sq jednostki, które możemy gdzieś zapisać. Gdy chcieliśmy wysłać dwóch, to zaraz byly jakieś problemy. To jest madra uwaga, tylko kompletnie nie mamy konceptu, jak to zrobić, jak się uporać z tymi uprzedzeniami. Ja też rozumiem tych rodziców, jak ktoś ma dzieci, to chce je chronić przed takimi właśnie [negatywnymi wzorami]. W mieście jest troszkę łatwiej wmieszać się $w$ to środowisko. (MOW_psycholog)

9. Wyniki naszych analiz wskazują na duże wewnętrzne zróżnicowanie problemów i potrzeb wychowanków MOS/MOW. Wychowankowie tych placówek przejawiają całe spektrum nasilenia zachowań problemowych/ryzykownych - od pojedynczych zachowań do bardzo rozbudowanego syndromu zachowań ryzykownych. W celu bardziej adekwatnej odpowiedzi na potrzeby tak zróżnicowanej grupy przydatna byłaby większa specjalizacja wewnątrz systemu ośrodków wychowawczych/socjoterapeutycznych. Specjalizacja ośrodków mogłaby dotyczyć z jednej strony młodzieży zagrożonej niedostosowaniem społecznym, która demonstruje 
on the other hand, youth at risk due to the consequences of a risky lifestyle, associated with the intensive use of psychoactive substances and risky sexual behaviuor. In this context, interviewees pointed to the need for sex education adapted to the students' real situation and requirements:

It is worthwhile finally to accept that our kids start their sex life very early - whether we like it or not. You just have to take it as a fact and you have to work on it, you have to talk about it and in fact you have to work with 16-year-olds just like with people who are sexually active, because unfortunately these are the facts. (MOW_director)

This is an interesting conclusion, because if almost a quarter do not use contraception at all (...), it is something that you actually need to work on. Then we have cases, even with us, that we have a 16-year-old father. This is already a tragedy for this kid, for one child and the another child. (MOS_ psychologist)

The centre specialisation could apply to young people with emotional or neurological problems that hinder or prevent the fulfillment of compulsory schooling in mainstream schools:

We at work see that every year more and more young people come to us with this kind of problem. Just suicidal thoughts, depressive states, there are more and more girls like this. (MOS_pedagogist)

\section{Recommendations for systemic solutions}

Implementing this kind of recommendation requires systemic solutions. This issue was raised in an official report of the Supreme Audit Office on MOW activities [23]. It stated, among other things, that there is a lack of specialised facilities for working on the specific youth dysfunctions at the MOW. As a result, the young people there display varying levels of risky behaviour, require addiction therapy, and suffer from dysfunctions and face problems that hinder educational progress. There is also a lack of adequate psychological and pedagogical care. Due to the insufficient psychologists and teachers' compulsory hours, they can devote no more than an hour per week to individ- przede wszystkim nasilone zachowania antyspołeczne (wykroczenia, przemoc, hazard), a z drugiej strony młodzieży zagrożonej ze względu na konsekwencje ryzykownego stylu życia, związanego $\mathrm{z}$ intensywnym używaniem substancji psychoaktywnych i ryzykownymi zachowaniami seksualnymi. Uczestnicy wywiadów w tym kontekście wskazywali na potrzebę edukacji seksualnej dostosowanej do rzeczywistej sytuacji podopiecznych:

Cenne jest to, żeby przyjąć wreszcie za fakt, że nasze dzieciaki rozpoczynaja życie seksualne bardzo wcześnie - czy nam się to podoba czy nie. Trzeba to po prostu przyjać za fakt i trzeba nad tym pracować, trzeba o tym mówić i rzeczywiście z 16-latkami trzeba pracować tak jak z osobami, które sa czynne seksualne, bo niestety takie sa fakty. (MOW_dyrektor)

To jest ciekawy wniosek, bo jeśli prawie jedna czwarta $w$ ogóle nie stosuje antykoncepcji (...), to jest coś, nad czym faktycznie trzeba popracować. Potem mamy przypadki, nawet u nas, że mamy 16-letniego ojca. To już jest tragedia i dla tego dzieciaka, dla jednego dziecka i dla drugiego dziecka. (MOS_psycholog)

Specjalizacja ośrodków mogłaby dotyczyć młodzieży z problemami natury emocjonalnej czy problemami neurologicznymi, które utrudniają lub uniemożliwiają realizowanie obowiązku szkolnego w zwykłych szkołach:

My w pracy widzimy, że z roku na rok coraz więcej przychodzi do nas młodzieży $z$ takimi problemami. Właśnie myśli samobójcze, stany depresyjne, coraz więcej jest takich dziewcząt. (MOS_pedagog)

\section{Rekomendacje dotyczące rozwiązań systemowych}

Wprowadzenie takich rekomendacji w życie wymaga rozwiązań systemowych. Kwestia ta została podniesiona $\mathrm{w}$ raporcie Najwyższej Izby Kontroli dotyczącym działalności MOW [23]. Stwierdzono w nim m.in. że brakuje placówek wyspecjalizowanych $\mathrm{w}$ pracy nad specyficznymi dysfunkcjami młodzieży kierowanej do MOW. W efekcie do tych samych ośrodków trafiają młodzi ludzie przejawiający różny poziom nasilenia zachowań ryzykownych wymagający terapii uzależnień, a także cechujący się dysfunkcjami i problemami utrudniającymi realizację obowiązku szkolnego. Brakuje ponadto odpowiedniej opieki 
ual students. Such limited time does not allow for effective, individualised therapy. Finally, there is a lack of a systemic care and support for students leaving the centres. As a consequence, these young people return to risky behaviour, and the longer they spend outsie the centre, the more likely they are to get in trouble with the law [23].

\section{Recommendations for further research}

Our study is a form of scientific support for preventive and resocialization work undertaken at the MOS/MOW. The insufficient number of research on the students of this type of institution is a serious systemic neglect as it increases MOS/MOW employees' feeling of being left with these difficult tasks without adequate support. Therefore, there is an urgent need to plan further research and extend it to mental health related issues. Our study was focused mainly on the problem of alcohol and other substance use as well as other problem/risky behaviours, so they only respond to this pressing need to a slight degree. Participants from the staff emphasised the need for cyclical nationwide studies to monitor the problems of young people at risk of social maladjustment. Projects of this kind are also a valuable source of reference for MOS/MOW internal research:

It all depends on the cyclical nature of these results. I'm glad that in the end we are, so to speak "on the agenda" with our resocialisation and educational institutions. Because if we have support in the form of cyclical insight into what is happening and what are our current trends, the usefulness of a report like this is undoubtedly significant. (MOW_ psychologist)

It is always useful that you can see and self-reference and compare what is going on in the facility with what has come out. To see what suits us and what action we can take. (MOS_psychologist) psychologiczno-pedagogicznej. Ze względu na niedostateczny obowiązkowy wymiar godzin zajęć psychologów i pedagogów mogą oni poświęcić poszczególnym wychowankom nie więcej niż godzinę tygodniowo. Tak ograniczony czas nie pozwala na prowadzenie skutecznej, zindywidualizowanej terapii. Wreszcie, brakuje systemu opieki i wsparcia dla wychowanków opuszczających ośrodki. W konsekwencji młodzież ta wraca na drogę zachowań ryzykownych, a im więcej lat upływa od opuszczenia ośrodka, tym większy odsetek ma problemy z wymiarem sprawiedliwości [23].

\section{Rekomendacje dla badań}

Nasze badania są rodzajem wsparcia naukowego dla pracy profilaktyczno-resocjalizacyjnej podejmowanej przez pracowników MOS/MOW. Niedostatek badań nad wychowankami tego typu placówek jest poważnym zaniedbaniem systemowym, ponieważ zwiększa u pracowników MOS/ MOW poczucie pozostawienia $\mathrm{z}$ tymi trudnymi zadaniami bez odpowiedniego wsparcia. Dlatego pilną potrzebą jest zaplanowanie dalszych badań i poszerzenie ich o kwestie związane z problemami zdrowia psychicznego. Nasze badania były nastawione głównie na problematykę picia alkoholu oraz używania innych substancji psychoaktywnych i innych zachowań problemowych/ ryzykownych, więc tylko $\mathrm{w}$ niewielkim stopniu odpowiadają na tę palącą potrzebę. Uczestnicy wywiadów podkreślali potrzebę cyklicznych badań ogólnopolskich w celu monitorowania problemów młodzieży zagrożonej niedostosowaniem społecznym. Takie projekty są też dla placówek MOS/MOW cennym źródłem odniesień dla ich wewnętrznych badań:

Wszystko zależy od pewnej cykliczności pojawiania się tych wyników. Cieszę się, że w końcu jesteśmy, kolokwialnie mówiąc, „na tapecie”, nasze placówki resocjalizacyjno-wychowawcze. Bo jeżeli będziemy mieli wsparcie $w$ postaci cyklicznego wgladu $w$ to, co się dzieje i jakie sa aktualne tren$d y$, to przydatność takiego raportu jest niewatpliwie znaczaca. (MOW_psycholog)

Przydatne zawsze jest to, że można zobaczyć i odnieść do siebie, porównać to, co się dzieje w placówce, z tym, co wyszło. Zobaczyć, co pasuje do nas i jakie działania podjąć. (MOS_psycholog) 
Summary of recommendations for MOS and MOW preventive work

1. Due to the widespread use of psychoactive substances and the intensification of harmful patterns of use of these substances among juveniles of MOS/MOW, we recommended the introduction of elements of harm-reduction in preventive work with these young people.

2. The mental health of MOS/MOW students should be the subject of care and particularly intensive activities. Research results indicate that drinking alcohol (and use of other psychoactive substances) can be a coping strategy for mental health problems.

3. Self-control is a factor that is important in reducing alcohol-related problems. Therefore, we recommend expanding the range of preventive and therapeutic sessions with trainings focused on developing self-control skills.

4. The tendency to sensation seeking appears to be one of the most important factors increasing drinking and risk of alcohol abuse. This indicates the need to expand the range of attractive and constructive recreational free-time activities. These sessions should be intensive and conducted regularly, and also meet MOS/MOW students' needs.

5. An important factor reducing the risk of drinking by MOS/MOW students is parents' control over how children spends their free time. Therefore, it is recommended to include parents in preventive activities targeting young people and enable them to participate in workshops improving their parental skills.

6. Young people who think they are free to use psychoactive substances are more likely to use them. This was also confirmed by our survey among MOS/MOW students. For this reason, we recommend preventive sessions based on normative education strategy, which consists of strengthening norms that prevent
Podsumowanie rekomendacji dla pracy profilaktycznej w MOS i MOW

1. Ze względu na rozpowszechnienie używania substancji psychoaktywnych i nasilenie szkodliwych wzorów używania tych substancji wśród wychowanków MOS/MOW, w pracy profilaktycznej $\mathrm{z}$ tą młodzieżą rekomendowane jest wprowadzenie elementów redukcji szkód.

2. Zdrowie psychiczne młodzieży przebywającej w MOS/MOW powinno być przedmiotem troski i szczególnie intensywnych działań. Wyniki badań wskazują bowiem, że picie alkoholu (i używanie innych substancji psychoaktywnych) może służyć jako metoda radzenia sobie z problemami zdrowia psychicznego.

3. Samokontrola jest czynnikiem, który ma istotne znaczenie w ograniczaniu problemów wynikających z picia alkoholu. Rekomendowane jest więc poszerzanie oferty zajęć profilaktycznych i terapeutycznych o treningi ukierunkowane na doskonalenie tej umiejętności.

4. Skłonność do poszukiwania silnych wrażeń okazała się jednym z najistotniejszych czynników sprzyjających piciu i nadużywaniu alkoholu. Wskazuje to na potrzebę poszerzania oferty atrakcyjnych i konstruktywnych form spędzania czasu. Zajęcia te powinny być intensywne oraz prowadzone regularnie, a także odpowiadać potrzebom wychowanków MOS/MOW.

5. Istotnym czynnikiem ograniczającym ryzyko picia alkoholu przez młodzież z MOS/MOW jest kontrola rodziców dotycząca tego, w jaki sposób ich dziecko spędza wolny czas. Rekomendowane jest więc włączenie rodziców do działań profilaktycznych adresowanych do młodzieży i umożliwienie im udziału w warsztatach doskonalenia umiejętności wychowawczych.

6. Młodzi ludzie, którzy sądzą, że wolno im używać substancji psychoaktywnych, są bardziej skłonni sięgać po te substancje. Potwierdziły to także badania wśród wychowanków MOS/MOW. $\mathrm{Z}$ tego względu rekomendowane jest prowadzenie zajęć profilaktycznych w oparciu o strategię 
the use of psychoactive substances by young people.

7. A good preventive strategy in working with young people is taking care of the positive social climate in schools and other educational institutions. Therefore, activities conducive to building a good social atmosphere should also be included in the MOS and MOW work system.

8. Positive relationships with peers increase the risk alcohol use and experiencing alcohol-related problems. Drinking alcohol by young people may be associated with peer group popularity and position. This indicates the need to introduce programmes the goal of which would be to create and support peer groups focused on achieving positive goals.

9. The results of our study in MOS and MOW indicate a large internal variation of students' problems and needs. An adequate response to the needs of such a diverse group requires greater specialisation within the system of facilities for at-risk youth.

Our study and the conclusions from the Supreme Audit Office report [23] point to the need to develop and implement comprehensive prevention and readaptation programmes to cover the wider social environment of MOS and MOW students and graduates. These prevention activities should have a cross-sectoral character and be based on the cooperation of various institutions operating in the local community (including education, social assistance, psychological and psychiatric assistance and non-governmental organizations). These programmes would support students' families also in their place of residence helping students join positive peer groups and social projects implemented in their local environment, continue education and, if necessary, receive specialist assistance. Systematic monitoring of problems experienced by young people at risk of social maladjustment and their families could also be a programme element. edukacji normatywnej, która polega na wzmacnianiu norm przeciwnych używaniu przez młodzież substancji psychoaktywnych.

7. Ważną strategią profilaktyczną $\mathrm{w}$ pracy $\mathrm{z}$ młodzieżą jest dbanie o pozytywny klimat społeczny szkół i innych placówek edukacyjnych. Działania sprzyjające budowaniu dobrego klimatu społecznego należy więc również uwzględniać w systemie pracy MOS i MOW.

8. Pozytywne relacje z rówieśnikami zwiększają ryzyko sięgania po alkohol i doświadczania związanych $\mathrm{z}$ tym problemów. Picie alkoholu przez młodzież może bowiem wiązać się z popularnością i pozycją w grupie rówieśniczej. Wskazuje to na potrzebę wprowadzania programów, których celem byłoby tworzenie i wspieranie grup rówieśniczych nastawionych na realizację pozytywnych celów.

9. Wyniki badań w MOS i MOW wskazują na duże wewnętrzne zróżnicowanie problemów i potrzeb wychowanków tych placówek. Adekwatna odpowiedź na potrzeby tak zróżnicowanej grupy wymaga większej specjalizacji wewnątrz systemu placówek przeznaczonych dla młodzieży z grup ryzyka.

Przeprowadzone przez nas badania oraz wnioski z raportu NIK [23] wskazują na konieczność opracowywani i wdrażania wszechstronnych programów profilaktyki i readaptacji, które będą obejmowały szersze środowisko społeczne podopiecznych i absolwentów MOS i MOW. Działania powinny mieć charakter międzysektorowy i być oparte na współpracy różnych instytucji funkcjonujących w społeczności lokalnej (w tym oświaty, pomocy społecznej, pomocy psychologiczno-psychiatrycznej, organizacji pozarządowych). Programy takie umożliwiłyby dotarcie do rodzin podopiecznych oraz zaoferowanie im pomocy w miejscu zamieszkania, zaś wychowankom włączenie się do pozytywnych grup rówieśniczych i projektów społecznych realizowanych w ich środowisku lokalnym, kontynuowanie edukacji oraz - $w$ razie potrzeby - pomoc specjalistyczną. Elementem tych programów mogłyby być także systematyczne monitorowanie problemów doświadczanych przez młodzież zagrożoną niedostosowaniem społecznym oraz ich rodzin. 


\section{Conflict of interest/Konflikt interesów}

None declared./Nie występuje.

\section{Financial support/Finansowanie}

The article was prepared within the frame of the research project financed by the National Health Programme for 2016-2020.

Artykuł został przygotowany w ramach projektu badawczego finansowanego ze środków Narodowego Programu Zdrowia na lata 2016-2020.

\section{Ethics/Etyka}

The project "Supporting research in the area of risk and protective factors associated with alcohol-use related problems" was approved by the Bioethics Committee of the Institute of Psychiatry and Neurology in Warsaw, Resolution No. 342017 of 26 October 2017.

Projekt „Wspieranie badań naukowych w obszarze czynników ryzyka i czynników chroniących przed problemami wynikającymi z picia alkoholu" uzyskał zgodę Komisji Bioetycznej Instytutu Psychiatrii i Neurologii w Warszawie, Uchwała nr 342017 z dnia 26 października $2017 \mathrm{r}$.

The work described in this article has been carried out in accordance with the Code of Ethics of the World Medical Association (Declaration of Helsinki) on medical research involving human subjects, Uniform Requirements for manuscripts submitted to biomedical journals and the ethical principles defined in the Farmington Consensus of 1997.

Treści przedstawione w pracy są zgodne z zasadami Deklaracji Helsińskiej odnoszącymi się do badań z udziałem ludzi, ujednoliconymi wymaganiami dla czasopism biomedycznych oraz z zasadami etycznymi określonymi w Porozumieniu z Farmington w $1997 \mathrm{r}$.

\section{References/Piśmiennictwo}

1. Jessor R, Jessor S. Problem behavior and psychological development: a longitudinal study of youth. New York: Academic Press; 1977.

2. Jessor R. Risk behavior in adolescence: A psychosocial framework for understanding and action. J Adolesc Health 1991; 12: 597-605.

3. Ostaszewski K, Rustecka-Krawczyk A, Wójcik M. Czynniki chroniqce i czynniki ryzyka zwiazane z zachowaniami problemowymi warszawskich gimnazjalistów: klasy I-III. Warszawa: Instytut Psychiatrii i Neurologii; 2011. http://www.ipin.edu.pl/wp-content/ uploads/2019/06/Raport.IPiN_2011_v10PRESS.pdf [Access: 24.09.2019].

4. Gaś ZB (ed.). Efektywność instytucjonalnych form pomocy na rzecz młodzieży zagrożonej wykluczeniem społecznym. Lublin: Pracownia Wydawnicza Fundacji „Masz szansę”; 2008.

5. Pisarska A, Bobrowski KJ, Greń J, Ostaszewski K. Risk and protective factors associated with alcohol and other substance use among students attending youth correctional centres: study design and methodology. Alcohol Drug Addict 2019; 32(4): 247-66.

6. Ostaszewski K, Bobrowski KJ, Greń J, Pisarska A. Intense risk behaviours among students attending youth correctional centres. Alcohol Drug Addict 2019; 32(4): 291-316.

7. Greń J, Bobrowski KJ, Ostaszewski K, Pisarska A. Prevalence of psychoactive substance use among students attending youth correctional centres. Alcohol Drug Addict 2019; 32(4): 267-90.

8. Bobrowski KJ, Greń J, Ostaszewski K, Pisarska A. Factors related to the alcohol use among students attending youth correctional centres. Alcohol Drug Addict 2019; 32(4): 317-36. 
9. Stęplewska-Żakowicz K. O różnorodności form wywiadu oraz prób jej uporządkowania. In: Stemplewska-Żakowicz K, Krejtz K (eds.). Wywiad psychologiczny. Wywiad jako postępowanie badawcze. Warszawa: Pracownia Testów Psychologicznych Polskiego Towarzystwa Psychologicznego; 2005, p. 17-30.

10. Zuckerman M. Behavioral expressions and biosocial bases of sensation seeking. New York: Cambridge Press; 1994.

11. Kelley AE, Schochet T, Landry CF. Risk taking and novelty seeking in adolescence: introduction to part 1. Ann N Y Acad Sci 2004; 1021: 27-32. DOI: 10.1196/annals.1308.003.

12. Steinberg L. Risk taking in adolescence. New perspectives from brain and behavioral science. Current Directions in Psychological Science 2007; 16(2): 55-9. http://www.jstor. org/stable/20183162 [Access: 24.09.2019].

13. Steinberg L. Risk taking in adolescence: what changes and why? Ann N Y Acad Sci 2004; 1021: 51-8. DOI: 10.1196/annals.1308.005.

14. Pisarska A, Eisman A, Ostaszewski K, Zimmerman MA. Alcohol and cigarette use among Warsaw adolescents: factors associated with risk and resilience. Subst Use Misuse 2016; 51(10): 1283-96. DOI: 10.3109/10826084.2016.1168442.

15. McCrystal P. Drug prevention for young people with social, emotional and behavioural difficulties attending special educational provision. Emotional and Behavioural Difficulties 2008; 13(4): 305-14.

16. Berkowitz AD. The social norms approach: theory, research and annotated bibliography. 2004. http://www.alanberkowitz.com/articles/social_norms.pdf [Access: 24.09.2019].

17. Borsari B, Carey KB. Peer influences on college drinking: a review of the research. J Subst Abuse 2001; 13(4): 391-424.

18. Borsari B, Carey KB. Descriptive and injunctive norms in college drinking: a meta-analytic integration. $J$ Stud Alcohol 2003; 64(3): 331-41. DOI: 10.15288/jsa.2003.64.331.

19. Ostaszewski K. Kompendium wiedzy o profilaktyce. In: Węgrzecka-Giluń N (ed.). Przewodnik metodyczny po programach promocji zdrowia psychicznego i profilaktyki. Warszawa: Fundacja ETOH; 2010, p. 73-95.

20. Hoel S, Eriksen B, Breidablik HJ, Meland E. Adolescent alcohol use, psychological health and social integration. Scand J Pub Health 2004; 32(5): 361-7. DOI: 10.1080/14034940410027894.

21. Demant J, Jarvinen M. Constructing maturity through alcohol experience - Focus group interviews with teenagers. Addict Res Theory 2006; 14(6): 589-602. DOI: https://doi. org/10.1080/16066350600691683.

22. Pedersen W, Kolstad A. Adolescent alcohol abstainers: traditional patterns in new groups. Acta Sociol 2000; 43(3): 219-33. DOI: http://dx.doi.org/10.1177/000169930004300303.

23. Najwyższa Izba Kontroli. Działalność resocjalizacyjna Młodzieżowych Ośrodków Wychowawczych. NIK; 2017. https://www.nik.gov.pl/plik/id,15816,vp,18331.pdf [Access: 28.11.2019]. 